\title{
Formality of Statutory Marriage in Nigeria: Need for a Policy-Driven Construction of the Marriage Act
}

\author{
Emeka Chianu*
}

\begin{abstract}
The Nigerian Marriage Act 1914 provides certain preliminary formalities which a prospective couple should comply with before celebrating statutory marriage. An examination of the reported decisions shows that the Act's potency is whittled down because the courts have failed to purposively construe its salient provisions. Even though the Act is a century old, no social or moral development justifies a change; so little is suggested to reform the formality part of the Act. Rather, the article undertakes a diligent examination of the Act to ascertain its object, and finds that it is the promotion of monogamy in a society where, for the most part polygamy is the norm. It proffers a construction of the Act that promotes this object. It also suggests a stern judicial attitude that urges each prospective spouse to conscientiously address his/her mind to his/her self-serving obligation to comply with the preliminary formalities in the Act.
\end{abstract}

\section{A. Introduction}

The history of the law in English jurisdictions is that when courts are saddled with a dispute they do their utmost to evolve principles to resolve it. A responsive parliament enacts a statute to refine, reform, or do away with the court-made law. The statute comes before the courts and if they are displeased with it, they construe the kernel of it out of potency and the law reverts to what it was prior to the statute. Two examples may suffice. The Land Registration Act 1924 (re-enacted as Land Instruments Registration Law in each State of the Federation) enacts in section 15 that only instruments affecting land which are registered may be admissible in evidence. The courts have almost construed this provision out of existence by interpreting 'instrument' narrowly so that almost all documents are admissible without registration. ${ }^{1}$ Another example: section 4 of the Statute of Frauds 1677 enjoins the docu-

* Professor Emeka Chianu, Faculty of Law, University of Benin, Benin City, Nigeria (E-mail: chianu_emeka@yahoo.com).

1 Elegbede v Savage (1951) 20 NLR 9 (receipt that evidences payment of money not registrable instrument); Akanni v Sijuwade (1952) 14 WACA 75 (unregistered instrument admissible if opponent admits its existence); Coke v Ogunye (1939) 15 NLR 57 (instrument prepared after oral transaction admissible even if unregistered); Okpatav Obo [1960] SCNLR 103 (instrument that evidences native law transfer admissible even if unregistered.) For a full discussion, see Chianu, Emeka, Law of Sale of Land, Lagos, Lawlords, 2008, chapter 13 (hereafter Chianu, Sale of Land.). 
mentation of transfer of interests in land, but courts of equity make a short shrift of it by formulating the doctrine of part performance. ${ }^{2}$

Something similar is true of the formality set out in the Marriage Act 1914 (MA or the Act). ${ }^{3}$ The Act is ancient, over a century old, yet its provisions on formality remain appealing. The formality for a valid marriage under the Act may be summarized: A prospective spouse gives notice of intention to marry to the registrar of marriage (Form A). ${ }^{4}$ The notice is published in the registry for three months. ${ }^{5}$ Twenty-one days after the publication of the notice but before the expiry of the three months the party deposes to an affidavit and the registrar of marriage issues him/her a certificate (Form C). ${ }^{6}$ Armed with Form C the parties approach a minister of religion in a licensed place of public worship, ${ }^{7}$ or a marriage registrar in his office ${ }^{8}$ where the marriage is celebrated and a certificate (Form E or any other certificate) is issued. What is the effect of non-compliance with this procedure? In part, section 33(2) answers:

A marriage shall be null and void if both parties knowingly and willfully acquiesce in its celebration

(a) In any place other than the office of a registrar of marriages or a licensed place of worship; or

(b) Without a registrar's certificate of notice or license issued under section 13 of this Act duly issued; or

(c) By a person not being a recognized minister of some religious denomination or body or a registrar of marriages.

Section 33(3) further attempts to save a marriage from being declared invalid by providing: "But no marriage shall, after celebration, be deemed invalid by reason that any provision of this Act other than [those set out in section 33(2)] has not been complied with".

An attempt is made to see if, in construing the Act, there is a policy that drives the courts. As the decisions that follow evinces, a couple can walk into a place of public worship, perform sacrament and later testify in court that they are ignorant of the MA formalities for a valid statutory marriage. And the courts hold them validly married so that the Act is honoured as much in the breach as in the observance! This writer's disquiet with these decisions is the fulcrum of this paper. At bottom the thesis proposed is that where a party

2 Maddison v Alderson (1883) 8 AC 467. For a detailed examination of the doctrine of part performance, see Chianu, Sale of Land, chapter 5.

3 Cap M6 Laws of the Federation of Nigeria 2004 (LFN 2004). Unless otherwise indicated, reference to sections is to the MA.

4 Section 7.

5 Section 10.

6 Section 11.In a future amendment of the Act the registrar's certificate should be renamed registrar's licence as this certificate is easily confused with the marriage certificate (Form E).

7 Sections 21 and 23.

8 Section 27. 
failed to prove that the preliminaries the Act stipulates are complied with before he purported to celebrate a statutory marriage, the marriage should be declared void. Also the celebration mentioned in section 33(3) should be one in furtherance with the Act not just any celebration anywhere.

\section{B. Judicial Attitude to Formalities}

The decisions on this point date back over half a hundred years. ${ }^{9}$ The earliest appears to be Onwudinjoh v Onwudinjoh. ${ }^{10}$ The suit was a succession claim. The plaintiff claimed that his siblings from a woman his father married after contracting a statutory marriage with his mother were illegitimate as his father's subsequent native law marriage was void for bigamy. To succeed he had to prove the statutory marriage between his parents. His mother testified that her marriage was contracted in a church. Another witness testified that records relating to the marriage in the church were lost. On this evidence the court held that an Act marriage was contracted. Ainley CJ raised a series of questions and answered them in the affirmative:

Am I to assume that the [clergyman who solemnized the marriage] was a fraud or did not know his legal duties? Am I to assume that the Church Missionary Society permitted the celebration of marriages in an unlicensed church? Am I to assume that because forty-year old records cannot be produced from an office in Makurdi that this lady was not lawfully married to the man she lived with for twenty years after a religious ceremony in a church? I do not think so. I think that I am entitled to presume, in the circumstances, that the Church was duly licensed and that the proceedings in the church were in accordance with the law. I would add that even if the church was unlicensed, and even if the registrar's certificate of notice was not issued, and even if the [clergyman] was not a "recognized minister" yet section 33(2) of the Marriage [Act] appears to have this effect that the marriage would not be void ... if the parties, or one of them were unaware of the defects mentioned. I feel quite sure that [the wife] had no knowledge one way or the other of the legal preliminaries to this marriage,

9 The decisions discussed are decades old but nothing has changed as evident that the most recent texts on Nigerian Family Law continue to rely on them. Since the 1980s, when the economy took a nosedive, High Court decisions have not been reported regularly. Chief Gani Fawehinmi, SAN published only one volume of High Court of Nigeria Law Report in 1985; he did not sustain it apparently because it had little patronage and so was not economically viable. He concentrated in publishing reports of Court of Appeal and Supreme Court of Nigeria decisions in the Nigerian Weekly Law Reports. For the most part, State Government-sponsored Law Reports have gone under perhaps as a result of the indolence that characterizes civil service.

10 (1957) II ERLR 1. In Agbo v Udo (1947) 18 NLR 152 the petitioner successfully claimed damages against the respondent for committing adultery with his wife. The only evidence of statutory marriage was that the parties celebrated it in a church. Abbott $\mathrm{J}$ held there was a Christian (by which he meant statutory) marriage. This decision is of minimal value to this article as his lordship made no reference to the MA. 
and I am quite sure that she did not knowingly and willfully acquiesce in any irregularity. My conclusion is that there is sufficient evidence to satisfy me that [the parties] were lawfully married under the $[$ Act $] .{ }^{11}$

A little less than a decade thereafter, Akuwudike v Akuwudike ${ }^{12}$ came before Idigbe J. The evidence the court accepted was that nothing in the form of a marriage under the Act was performed: no application was made to the marriage registrar; consequently, the registrar's certificate was not obtained. Indeed, none of the parties as much as attempted to comply with the formalities set out in the MA. Rather, the clergyman who solemnized the marriage affirmatively testified that the MA's formalities were not complied with. Yet his lordship held there was a statutory marriage because the petitioner, the wife, acted in ignorance of the law. He said:

If the particular Roman Catholic Church (as in the instant case) was licensed under the [Act] for the performance of marriages it is my view that marriages performed in such a place - in accordance with any particular usage of that Church - must (unless invalid within the provisions of section 33(2)) be presumed valid under the [Act] if it was the intention of the parties to go through a form of Church marriage recognized by the [Act]; provided it was celebrated [in accord with section 21].... Where there is evidence of marriage having been performed in this country in accordance with the rites of the Church and parties to it have lived as husband and wife and cohabited together, everything necessary to ensure the validity of the marriage should be presumed in the absence of decisive evidence to the contrary.

The petitioner ... had no knowledge of the legal requirements of a valid marriage under the [Act] and she told me that it was her intention and belief that she was going through a form of marriage recognized by both the Church and the [Act].I am also satisfied that she did not willfully and knowingly acquiesce in any irregularity (1) on the part of the officiating minister (who should have obtained a certificate under section 11 from the parties) (2) on the part of the husband. ${ }^{13}$

Some ten months later Palmer J decided Obiekwe v Obeikwe. ${ }^{14}$ The parties were already husband and wife by native law before they attempted to contract an Act marriage. About a year later the wife petitioned for judicial separation and the respondent challenged the court's jurisdiction on the grounds that the marriage solemnized was invalid under the Act as the registrar's certificate was not issued prior to the church blessing. The slender evidence of formality that preceded the Act marriage was that the husband gave notice to the marriage registrar under section 7 (Form A).The clergyman who solemnized the marriage

11 Ibid at 3-4. Emphasis supplied.

12 (1963) 7 ENLR 5.

13 Ibid at 6-8. Emphasis supplied.

14 (1963) 7 ENLR 196. 
testified that he did not think he was performing an Act marriage. ${ }^{15}$ The marriage was held valid. The reasons Palmer J gave are set out below:

The man knew ... that no certificate had been issued but did not realize that it was necessary, while the woman did not know whether any certificate had been issued or not, and did not know that such a certificate was necessary. Both parties believed that they were contracting a valid marriage. Neither party was aware of any defect. The woman was not aware that a certificate had not been issued ... In these circumstances I find it hard to see how the woman at least, can be said to have "knowingly and willfully acquiesced" in the celebration of the marriage "without a registrar's certificate of notice".

... I am also of opinion that the statute is not so stringent and that even if the petitioner had known that the certificate had not been issued, she would still be validly married if she did not know that a certificate was necessary and genuinely believed that she was contracting a valid marriage. ${ }^{16}$

The 1970s produced three reported decisions on the issue. In Akparanta $v$ Akparanta ${ }^{17}$ the petitioner who prayed for dissolution of marriage did not prove compliance with the Act. She testified that she relied on the respondent's assurances that he had complied with the preliminaries required for a valid statutory marriage. The certificate tendered as evidence of an Act marriage was issued in a church. On this evidence it was held that a valid statutory marriage was contracted. Agbakoba J, a highly competent and sound judge with a gift for lucid exposition of principle, reasoned:

Considered in the perspective of [section 33(2)(c)], I cannot say in the face of respondent's assertion or petitioner's denial or vice versa that both parties knowingly and willfully acquiesced in the celebration of the marriage without the registrar's certificate. In order to raise section 33(2)(c) as an objection to the validity of the marriage it must be shown that both husband and wife acquiesced in its celebration without the registrar's certificate. It is not enough if the evidence establishes acquiescence by one party and the other party acted in complete ignorance of the requirements, and the case would be stronger if it was the wife who so acted, relying, as in this case, on the husband to perform the preliminaries. The raison d'etre of the provision is to protect the unsuspecting party, usually the wife, from the exploitation of her ignorance of the statutory requirement or her confidence in the party, usually the

15 Was this testimony prompted by fear of being charged for offending s. 42 which stipulates five years imprisonment for any person who acts as marriage officer knowing that the formalities in the Act have not been performed? Agbakoba $\mathrm{J}$ whittled down this penal provision by holding that the charge against an officer is sustainable only after the marriage is declared invalid: Akparanta $\mathrm{v}$ Akparanta (1972) 2 ECSLR 779.

$16 \mathrm{Ibid}$ at 198. Emphasis supplied.

17 (1972) 2 ECSLR 779. 
husband, in arranging the marriage. To establish acquiescence, there must be evidence to show that the petitioner tacitly agreed to or indifferently accepted respondent's reluctance to obtain the registrar's certificate. ${ }^{18}$

Next in chronology came Mariazu v Mariazu. ${ }^{19}$ The facts are unusual because the petitioner testified that she was desperate to contract a marriage as she was pregnant by the respondent. Her paramour did not meet the obligations her relatives imposed on him for a native law marriage. Perhaps as a result of the civil war the Divisional Officer who doubled as marriage registrar could not be found to perform his duties under the Act. So the parties obtained a church blessing at a place that was not licensed for celebration of marriage. Her petition for custody of the child and maintenance under sections 70 and 71 of the Matrimonial Causes Act $1970^{20}$ failed as the court declined jurisdiction. On the formal validity of the marriage, Anyah J brushed Akuwudike aside and said:

I hold that any party who intends to contract a marriage under the Marriage Act ... and who knows that the registrar's certificate ... is essential to the validity of the marriage and yet goes through the ceremony of the marriage without the said certificate, knowingly and willfully acquiesces in the celebration of the said marriage. It is immaterial that the parties had made unsuccessful efforts to obtain the registrar's certificate. $^{21}$

Relevantly, this decision is of little value in this work because the court had affirmative testimony that both parties knew that the statutory conditions precedent were not complied with. It was easy for his lordship to declare the marriage null under section 33(2) of the MA.

Different from any other decision is Ajih $\mathrm{v}$ Ajih. ${ }^{22}$ The parties approached a clergyman who solemnized their marriage, inserted their name in a marriage register which was in the church's custody and proclaimed them man and wife. When the lady petitioned for judicial separation, the respondent challenged the court's jurisdiction as he never entered into statutory marriage with her. She testified that she imagined that the sacrament was all that was needed to contract a valid statutory marriage. The court ruled that it lacked jurisdiction to hear the petition in the absence of proof of the statutory formality that preceded the ceremony in church. In a broad judgment that deserves a wider currency, Araka J stated:

$18 \mathrm{Ibid}$ at 784-85. Emphasis supplied.

19 (1973) 3 ECSLR (pt II) 671

20 Cap M7 Laws of the Federation of Nigeria 2004.

21 (1973) 3 ECSLR (pt II) at 676.

22 (1975) 5 ECSLR 6. It is remarkable that neither Nwogugu, E. I., Family Law in Nigeria, $3^{\text {rd }}$ ed, Ibadan, HEBN, 2014 (hereafter Nwogugu, Family Law) nor Sagay, I., Nigerian Family Law: Principles, Cases, Statutes and Commentaries, Lagos, Malthouse, 1999 (hereafter Sagay, Family Law) refers to this decision. 
[The parties] fail to realize that marriage creates a status. The status of the parties is a matter of State laws and not of canon law. So that a marriage which may be a valid marriage under the canon law may not necessarily be of any legal effect under State law.

It is true that it has been the practice of the courts, where there is evidence of a marriage having been celebrated and the parties lived together and cohabited as husband and wife, that everything necessary to ensure the validity of the marriage should be presumed. But the courts have clearly laid down the rule that this presumption can only arise where there is no decisive evidence to the contrary.

[To presume the validity of a marriage which is at variance with the requirements of the Act] would be to repeal ... all the provisions of the Marriage Act. The court ought not by judicial interpretation make nonsense of statutory requirements. ${ }^{23}$

The Supreme Court decision in Anyaegbunam v Anyaegbunam ${ }^{24}$ is the closest opportunity the apex court had to address this issue and it fell into the same error as the High Courts. The petitioner sought judicial separation and other ancillary reliefs under the Matrimonial Causes Act 1970.To succeed she had to prove that her marriage was under the MA. By way of preliminary objection, the respondent challenged the High Court's jurisdiction on the ground that the marriage contracted was under native law followed by a church blessing. The court of trial ruled that it was seised with jurisdiction as the petitioner believed that she underwent a monogamous marriage and did not know that a registrar's certificate was necessary. The Supreme Court reversed him on this central plank: the petitioner did not testify to provide facts upon which the trial court reached his conclusion. Fatayi-Williams JSC noted:

The respondent testified in categorical terms that no registrar's certificate was obtained before the [church] ceremony. Not only did the petitioner not dispute this statement, she did not think it prudent enough to go into the witness box, as had been done by the petitioners in [Akuwudike and Obiekwe] and testify that the omission to obtain the necessary Registrar's Certificate was not done "willfully and knowingly". This omission on her part ...makes the purported marriage null and void. ${ }^{25}$

Inferentially, if the petitioner had testified as did the ladies in Akuwudike and Obiekwe the Supreme Court would have held the marriage valid.

23 Ibid at 8-11.

24 [1973] NSCC 224. See Nwogugu, E. I., The Validity of Church Marriages in Nigeria: Anyaegbunam $\mathrm{v}$ Anyaegbunam, in: Nigerian Law Journal 8 (1974), p. 142 (this incisive case comment focused more on proof of statutory marriage than on the validity of church marriages.).

25 Ibid at 228. In Chukwuma v Chukwuma [1996] 1 NWLR (pt 426) 543, 560, Achike JCA referred to Anyaegbunam as locus classicus "which places it beyond doubt that a celebration of marriage which to the knowledge of the parties has not been preceded by the issuance of the registrar's certificate is ineffectual, null and void." A careful reading of Anyaegbunam belies this conclusion. 
But for Maraizu and Ajih, the unhappy legacy of the judicial attitude is that the entire formal requirements of the MA are brought to nothingness. What can be distilled from most of the decisions is that the judges were inclined to uphold marriages celebrated in church in order to protect them from being declared invalid, ${ }^{26}$ or to protect the repute of the then established churches - Roman Catholic Mission and Church Missionary Society. ${ }^{27}$ For the most part judges have held the formalities in the Act with little regard, proceeding as if they were moral adjurations inserted to be complied with or disregarded whimsically. The courts were called upon to rely on the testimony of women and the judges, all male, appear to have been taken in by the sly of the witnesses. How much better if they were armed with Njiribeako J's warning on how to treat the testimony of witnesses who paint a gloomy picture of oppression and seek to use it as a ploy to win a judge's sympathy either in evaluating evidence or applying the law. His lordship adjured:

The court must be wary not to allow sympathy to run away with the mind and throw facts out of focus. It does the image of justice no good if sympathy is allowed to sway the court's judgment unnecessarily. ${ }^{28}$

\section{Writers' Response}

Over the years the judicial assault on the formalities set out in the MA has disturbed several legal writers. Shortly after Onwudinjoh was decided Obi criticized it on account that the evidence relied on to uphold the Act marriage and thereby disinherit the children of the subsequent native law marriage was too slender. ${ }^{29}$ Since Obi's attention was on the question of succession he wrote nothing about the formalities set out in the MA.

Writing in 1965, Ezeani treated Onwudinjoh and Akuwudike step motherly. ${ }^{30}$ Relying on Onwudinjoh he concluded that there was a strong presumption that a religious ceremony of marriage of which the records had been lost was performed in accordance with the Act. And he used Akuwudike as authority for the view that if parties intended to contract a monogamous marriage under a religious ceremony in the church of their denomination, thinking it would be a valid monogamous marriage it would be treated as an Act marriage unless both parties knew that the mandatory provisions of the Act had not been complied with.

26 Onwudinjoh, Akuwudike, Obiekwe and Akparanta.

27 Onwudinjoh and Akparanta respectively.

28 Onyeohuhu v Nwosu [1978] IMSLR 267, 273. To a similar effect are the words of Peter-Odili JSC: "A judge is well advised to keep his emotions in check at all times in order not to deviate from the matter before him"; Amobi v Nzegwu [2014] 2 NWLR (pt 1392) 510, 560.

29 Obi, S. N. C., The Effect of Ordinance Marriage on the Rights and Status of the Spouses, in: Journal of African Law 6 (1962), p. 49.

30 Ezeani, A. O. N., The Legal Effect of Religious Marriages: Recent Cases in Eastern Nigeria, in: Nigerian Law Journal 2 (1965), pp. 227, 231. 
At the time Kasumu and Salacuse published their work in 1966 only Onwudinjoh, Akuwudike and Obiekwe were decided. In this context they made no reference to Onwudinjoh but with respect to the other two they warned that the conclusions reached could produce astonishing and undesirable results if not kept within bounds. ${ }^{31}$

Although writing in 2013, the authoritative Nwogugu discussed only Akuwudike and Obiekwe. He concluded that where parties intend to contract a statutory marriage marry in church without complying with the requirements of the MA, the marriage may be regarded as valid. Then he noted, rather weakly, that this conclusion is not free from difficulties because of the problem of establishing the real intention of the parties at the relevant moment. $^{32}$

\section{The Marriage Act: What Interpretative Approach?}

The present writer ventures to say that, on this subject, no judge or writer has given the MA the vigorous exegesis it deserves. When a judge is called upon to construe and apply a statute he should keep in mind that he is not approached because he is a linguist or a grammarian. Legal training, experience and the benefit of arguments of counsel should aid him to first read the statute in its entirety and ascertain its purpose. Only then can he begin to give words in the statute a meaning that accords with parliamentary intent and sensibly apply the statute to resolve the disputes brought before him. This approach demands mental exertion on the part of a judge, yet slothfulness should not characterise a judge's style. What is more, he should dutifully give critical importance to policy considerations. In this respect Lord Scarman adjures:

Judges may not interpret statutes in the light of their own views as to policy. They may, of course, adopt a purposive interpretation if they can find in the statute read as a whole or in material to which they are permitted by law to refer as aids to interpretation an expression of Parliament's purpose or policy. ${ }^{33}$

In our opinion, none of the judges referred to above attempted this. As the judgments on the issue of formality show the courts have been persuaded more by what smacks of sentiments - to protect the fair sex - than ascertainment of policy from a diligent study of the Act.

A careful reading of the MA shows that its uncompromising and comprehensive purpose is to publicize statutory marriages. The publicity scheme of the Act may be summarised: the notice of marriage any prospective spouse gives to the marriage registrar is entered in a marriage notice book which any person may inspect during office hours without fee. The marriage registrar also publishes the notice by causing a copy of the same to be

31 Kasumu, A. B. / Salacuse, J. W., Nigerian Family Law, London: Butterworths, 1966, 165 (hereafter Kasumu and Salacuse, Family Law). Sagay, Family Law, expresses no commendation or condemnation on the decisions.

32 Nwogugu, Family Law, p. 150.

33 Shah v Barnet London BC [1983] 1 All ER 226, 238. 
affixed on the outer door of his office until three months have elapsed. ${ }^{34}$ Is this a casual provision that can be ignored without any consequence? Assuredly no, as section 12 provides that any marriage celebrated three months after the notice of marriage is issued shall be void. If the parties seek a valid marriage they would have to serve fresh notice. After a marriage is celebrated the marriage certificate (Form E) is filed in the marriage register book, and the registrar is obliged to allow searches to be made in the book, and give certified copies therefrom to any person upon payment of the prescribed fee. ${ }^{35}$ This entire scheme would be rendered lame if parties were at liberty to flout these formalities and escape sanction by claiming that they did not know of the existence of the Act or its requirements for a valid marriage.

In the main, the object of registration is to give publicity to private arrangements so that the public is not misled into taking steps the statute condemns. No one who reads the Act will deny that one of its objects is to promote monogamous marriage in a society that practices polygamy. ${ }^{36}$ This is evident in the provisions of sections 35, 39, 46 and 47 which not only render any bigamous marriage void but stipulate a penalty of five years imprisonment on any person who is convicted for offending the provisions. ${ }^{37}$ How is a person to know that a fiancé or fiancée is not already married if there is no public document he can search or consult? If a lady and a gentleman can walk into any church, solemnize marriage and feign ignorance of the formalities the MA imposes on them, what opportunity does a person have to enter a caveat against a proposed marriage as set out in sections 14 to 16 of the Act?

\section{E. Knowingly and Willfully: What They Should Mean}

The knowledge section 33(2) refers to is of facts set out in the subsection, not of the law. The MA could not have intended the disregard of the longstanding commonplace maxim ignorantia legis neminem excusat. Ignorance of law is different from ignorance of facts; the two should be kept separate. Sadly, most of the judges who commented on this subject imagined that the subsection refers to knowledge of the law. This can be seen in the itali-

34 This notice is similar to banns but they are not the same. Banns are published in the outer door of some established churches. Civil law considers it a matter of usage or custom. In contrast, the notice the Marriage Act provides for is a statutory condition precedent to a valid Act marriage.

35 Section 30.

36 "The main intention of the legislators was to bring the concept of monogamous marriage into Nigeria. This was considered necessary because of the hostility of the early missionaries who believed that it was unchristian for a man to have more than one wife": Kasunтu and Salacuse, Family Law, 12. Also see Oyebanji, M. B., The Place of Polygamy in the Nigerian Law, in: Nigerian Journal of Contemporary Law 13 (1981-83) pp. 19, 22; Olomola, O., Polygyny: A Legal Debate To Be or Not to Be? in: University of Ibadan Journal of Private and Business Law 6 (2011), p. 146 (it is interesting to read a female writer urge the legalising of polygyny, the practice of one man marrying many wives).

37 Also see s. 370 of the Criminal Code; $R$ v Princewill [1963] NNLR 54. 
cised portions in the judgments of Ainley CJ, Idigbe J, Palmer J and Agbakoba J quoted above. With respect, only Araka J got his act right when he essayed: "The provisions of the Marriage Act are there for everyone. Ignorance of the Act cannot, and will not, be any defence in law." ${ }^{38}$ Of course, there is nothing in these sentences suggestive that his lordship intended to address the phrase "knowingly and willfully" in the Act.

Section 33(2) excuses parties to an Act marriage from having their union annulled if they can prove that they did not knowingly and willfully acquiesce in flouting the formalities the Act stipulates. The only known judge who attempted an interpretation of "knowingly and willfully" is Palmer J when he said, "knowingly by itself might be ambiguous". ${ }^{39}$ There is nothing ambiguous about knowledge. Knowledge, or notice, has been classified into actual, constructive and imputed. We are thankful to Peter Gibson J for a careful exposition of what knowledge should mean. He said:

Knowledge can comprise any one of the five different mental states as follows:

(i) Actual knowledge;

(ii) Willfully shutting one's eyes to the obvious;

(iii) Willfully and recklessly failing to make such inquiries as an honest and reasonable man would make;

(iv) Knowledge of circumstances which would indicate the facts to an honest and reasonable man;

(v) Knowledge of circumstances which would put an honest and reasonable man on inquiry. ${ }^{40}$

Leaving out actual knowledge which is not contentious, it is for the courts to consider whether constructive knowledge should be applied to the issue on hand. It goes without saying that when parliament used "knowingly" it left for the courts the duty to supplement the meaning by drawing on the established common law principle that knowledge includes the broader constructive and imputed knowledge. Constructive and imputed knowledge are integral as well as indispensable in determining a person's state of mind. The publicity object of the Act would be meaningless if this much broader meaning of "knowingly" is not applied.

Whether or not constructive knowledge should be applied to a situation is largely dependent on whether the transaction is instantaneous, not affording the party to be imposed adequate time to investigate the facts or if he had sufficient time to obtain facts which good sense imposes on him. Marriage definitely comes within the latter. Anyone who rushes into statutory marriage without investigating what the law imposes on him would come within category (iii) above. The court has a duty to the public to impute knowledge of facts on a person even though he claims lack of actual knowledge a reasonable person would have.

38 Ajih v Ajih (1975) 5 ECSLR at 9.

39 Obiekwe v Obiekwe (1963) 7 ENLR at 198.

40 Baden, Delvaux and Lecuit v Societe General [1983] All ER Annual Review 352. 
Constructive knowledge is quite simply essential for the law to work. It would be intolerable for the courts to permit a party to escape liability merely by saying that he had no actual knowledge of certain facts thereby rendering the statute otiose.

We urge for the application of constructive knowledge to this situation because the events that lead up to a statutory marriage do not take place in a few days. In many cases the parties are already married under native law; ${ }^{41}$ in others they cohabit for months or more before marriage. Even where these are not the case the statutory provision for a 21 day notice preceding the issuance of Form $\mathrm{C}$ is intended by Parliament, we believe, to enable the parties verify vital facts before marriage. Any person who counter-argues should ask himself if a person who seeks to take such a major life changing step as marriage should not doubly assure himself that the fundamentals have been performed.

Imputed knowledge arises where a person acts through the agency of another. The law imputes the knowledge which the agent has on his principal. The law does not permit a principal to deny knowledge which the agent acquires in the course of his service to his principal. ${ }^{42}$ Applied to the issue on hand, where a lady claims that she relied on her prospective husband to perform the preliminaries for statutory marriage and the latter failed but assured her that the needful had been done, she should be bound by the gentleman's knowledge. Martins $\mathrm{v}$ Adenugba ${ }^{43}$ is not a decision on whether the formality of a marriage was complied with but the facts show what could happen between prospective spouses. The plaintiff whose testimony was not impugned said the defendant took her to the marriage registry; he went inside and left her outside. Later the same day he informed her that all formalities for marriage had been complied with and the next step was to proceed to church for a blessing of the union. This was done and the church issued them a certificate. Some three years after living as husband and wife, the plaintiff sought to dissolve the marriage. It was in the course of her legal practitioner's preparation to file a petition that it came to light that the defendant did nothing in furtherance of the preliminaries for a statutory marriage. The plaintiff's claim for damages for breach of a promise to marry succeeded. This story is seven decades old but it cannot be said that its commonplaceness is doubtful. A person lady or gentleman - who relies on a prospective spouse's assurances and fails to verify the truth should not be allowed to escape the legal consequences of his/her inaction.

"Willfully" involves free will, voluntariness. ${ }^{44}$ From of old judges have known that any mischievous or dishonest person can deny intending the consequences of his action. To ensure he does not escape with his half-truth the law imposes on him the ordinary consequences of a reasonable person, replacing what he may say is his subjective intent with an

41 Obiekwe, above; Ijioma v Ijioma [2009] 12 NWLR (pt 1156) 593, CA.

42 Orasanmi v Idowu [1959] NSCC 33, 36. For a full account of the law on imputed knowledge, see Watts, P., Imputed Knowledge in Agency Law - Excising the Fraud Exception, in: Law Quarterly Review 117 (2001), p. 300.

43 (1946) 18 NLR 63; Akparanta v Akparanta (1972) 2 ECSLR 779.

44 Arrowsmith v Jenkins [1963] 2 QB 561 (willful obstruction of highway); Lewis v Cox [1985] QB 509 (willful obstruction of police in the execution of his duty). 
objective one. The fact that a party says he did not intend to flout the Act is of no moment. It is enough that he took deliberate steps which, objectively regarded, amount to a statutory marriage.

\section{F. Section 33(3): What Should 'Celebration' Mean?}

Section 33(3) MA provides that no marriage shall, after celebration, be deemed invalid by reason that any provision of the Act other than those set out in section 33(2) has not been complied with. If 'celebration' in this subsection is given a broad meaning it can render the entire formality provisions of the Act nugatory. If it means any celebration anywhere (private residence, workshop, along the street, in a hotel room), and registration by any impostor (a class teacher, a housekeeper, a chauffeur) statutory marriage would be a laughingstock. Parliament could not have intended that where two parties walk into a church to solemnize marriage or call friends and well-wishers together at a civic reception in the name of marriage then they should be deemed to have complied with the Act and the ceremony should be declared valid.

Words take their meaning from context; without context words can be ambivalent, ambiguous, nonsensical or even meaningless. Within a broad doctrine of interpretation 'celebration' in section 33(3) should mean a celebration that accords with the Act to a considerable degree. The marriage in the subsection cannot be native law or church sacrament or social feast. It must be a marriage with which the MA is concerned, a marriage that purports to be celebrated under the Act. This would be so where the parties have taken steps as prescribed by the Act such as obtaining Form A or applying for Form C et cetera. ${ }^{45}$

\section{G. Conclusion}

A central plank in this article is that the formalities in the MA should be complied with; at the very least the marriage registrar's certificate (Form C) should be obtained. By section 10 this Form is registered and it is accessible to the public. The publicity provides valuable information to the public and ensures that the unsuspecting is not taken in by a treacherous person who seeks to deceive another into a bigamous union. True, the Act provides facilities for private arrangement between individuals. Yet, the validity of marriage affects status and so the public interest is involved. ${ }^{46}$ The courts should assess the demands of society for protection from persons who claim to be married but are not statutorily.

Some may urge that the requirements of registration should not be strictly insisted on in a country with scattered communities, poor communication, also indolence and corruption

$45 R$ v Ali Mohammed [1964] 2 QB 350n (decided in 1943); $R$ v Bahm [1965] 3 All ER 124. In both cases it was held that marriage contracted by Muslim clerics without compliance with the English Marriage Acts 1836 and 1949 did not confer on the couples the status of marriage recognised by English law and so the clerics did not offend the Act.

46 Hughes v Hughes [1958] pp. 224, 228 per Hudson LJ. 
on the part of some government officials. Regardless, the construction this article favours is not insensitive to social conscience as statutory marriage is not the only form of marriage recognised in the country. Persons are at liberty to marry under native law or Islamic law; nothing obligates persons who contract these types of marriage to register their union for it to be valid. So if a couple opts for an Act marriage, they should comply with it. There should be no half measures.

Indeed, Article 1 of the United Nations Convention on Consent to Marry, Minimum Age for Marriage and Registration for Marriages 1962 provides that no marriage shall be legally entered into without due publicity. Article 6(d) of the Protocol to the African Charter on Human and Peoples' Rights on the Rights of Women in Africa 2000 stipulates that every marriage shall be recorded in writing and registered in accordance with national laws, in order to be legally recognised. These international instruments show that registration of marriage has been the international standard for decades. They should not be ignored on account of expediency. If we cannot insist on having native law and Islamic law marriages registered, the same laxity should not be extended to statutory marriage. What is advocated may produce drastic consequences yet everything comes with a price. Most things in life are not this and that, but this or that. 